\title{
Allozyme variation in Transcaucasian populations of Aegilops squarrosa
}

\author{
ALEXANDER J U. DUDNIKOV \\ Institute of Cytology and Genetics, 630090 Novosibirsk, Russia
}

\begin{abstract}
Genetic variation at 27 enzyme loci was studied in 24 Transcaucasian populations of Aegilops squarrosa: $12 \mathrm{ssp}$. eusquarrosa and $12 \mathrm{ssp}$. strangulata populations. Most of the genetic variation was among populations: $G_{\mathrm{ST}}$ accounted for 0.67 and 0.64 for ssp. eusquarrosa and ssp. strangulata, respectively. The Acph1, Est2, Est5, Got1 and Got2 loci were found to be involved in the adaptive process of Ae. squarrosa subspecies divergence. Allele variation at the Ep locus is most likely to be neutral. The remaining 21 enzyme loci are under purifying selection of different intensities.
\end{abstract}

Keywords: Aegilops squarrosa, allozymes, genetic structure, natural selection, speciation.

\section{Introduction}

Aegilops squarrosa L. is a diploid self-pollinating goatgrass species which has contributed the D genome to common wheat (Triticum aestivum L.). Its importance as a potential donor of desirable genes for the improvement of cultivated wheats has aroused interest in investigating genetic variation in this species. Studies of variation among geographically diverse accessions of Ae. squarrosa from the world germ-plasm collections have been carried out using molecular markers, such as allozymes (Jaaska, 1980, 1981, 1984; Lagudah \& Halloran, 1989; Dudnikov \& Goncharov, 1993), storage proteins (Lagudah \& Halloran, 1988) and DNA markers (Lubbers et al., 1991). Information on the extent of genetic variation in $A e$. squarrosa and the general geographical patterns of this variation through the species range have been obtained. Two problems have been identified, which are essential for understanding processes of evolution and also for the development of an appropriate and efficient conservation strategy: (i) Ae. squarrosa intraspecies divergence; and (ii) the genetic structure of Ae. squarrosa populations. Such studies need plant material collected in primary habitats of $A$ e. squarrosa which are representative of gene frequencies in local populations of the species.

Despite a long history of studies on Aegilops systematics, the constitution of subspecies in $A e$. squarrosa is not clear. Eig (1929) identified two

Correspondence. E-mail: kosterin@bionet.nsc.ru subspecies: ssp. strangulata Eig with a markedly moniliform appearance of the spike, and ssp. eusquarrosa Eig (= ssp. tauschii Hammer) with a cylindrical type of spike. In reality, these two typical forms are connected by a continuous range of intermediate forms. This presents a problem for researchers as a considerable number of plants can not be unambiguously assigned to either of the subspecies (Jaaska, 1981; Lagudah \& Halloran, 1988). Therefore, distinguishing between Ae. squarrosa subspecies is largely subjective. Tanaka (1983) assigns to ssp. strangulata only plants with a sharply defined moniliform spike, which occupy the narrow belt along the south-eastern Caspian shore near Gorgan in Iran. According to Jaaska (1981), ssp. strangulata is morphologically more variable and inhabits eastern Armenia, Azerbaijan, Nakhitshevan, Northern Iran and Western Kopet-Dag in Turkmenistan. Zhukovsky (1928) divided Ae. squarrosa into three subspecies.

The objectives of this work, besides the study of Ae. squarrosa intraspecific differentiation and the genetic structure of Ae. squarrosa populations, were to investigate the nature of allozyme variation in $A e$. squarrosa populations and the role of allozymes in the process of speciation.

\section{Materials and methods}

Plant material was collected in 1989 in Armenia and Azerbaijan, and in 1990 in Dagestan (Table 1, Fig. 1) in Ae. squarrosa primary habitats. Aegilops 
squarrosa is distributed in hilly or mountainous regions where its primary habitats are dwarf-shrub steppe-like formations, usually just below the edge of a forest belt. In such habitats Ae. squarrosa makes up about 10 per cent of the herbage. Populations in secondary habitats were not used for seed collection. Seeds of Ae. squarrosa were collected randomly as separate spikes from mature plants at each of the 20 locations. One seed from each spike was germinated and analysed electrophoretically.

Leaf tissue of 2-3-week-old green plants was homogenized as described by Hart \& Langston (1977). Sixteen enzyme systems were used: aconitate hydratase (ACO, EC 4.2.1.3), acid phosphatase (ACPH, EC 3.1.3.2), aldolase (ALD, EC 4.1.2.13), catalase (CAT, EC 1.11.1.6), endopeptidase (EP, EC 3.4.21-24.-), esterase (EST, EC 3.1.1.2), glyceraldehyde-3-phosphate dehydrogenase (GAPD, EC 1.2.1.12), glutamate dehydrogenase (GDH, EC 1.4.1.2), glutamatic-oxaloacetatic transaminase (GOT, EC 2.6.1.1), general protein (GP, EC
4.1.1.39?), glucose-6-phosphate isomerase (GPI, EC 5.3.1.9), leucine aminopeptidase (LAP, EC 3.4.11.1), malate dehydrogenase (MDH, EC 1.1.1.37), NADH diaphorase (NADHD, EC 1.6.4.3), phosphoglucomutase (PGM, EC 2.7.5.1) and shikimate dehydrogenase (SKDH, EC 1.1.1.25).

A polyacrylamide gel electrophoretic system with 0.25 м Tris-0.1 м HCl gel buffer (Jaaska, 1981) was used for EP and GOT. Starch gel electrophoresis was performed horizontally on 12 per cent starch gels cooled with ice packs. A Tris-EDTA-maleic acid system, pH 7.4 (Brown et al., 1978) was used for GP, LAP and NADHD. LiOH-borate, $\mathrm{pH}$ 8.3, was used for ACPH, ALD, CAT, EST and GPI; and $0.02 \mathrm{M}$ histidine-citrate, $\mathrm{pH} 7.0$, was used for the other enzymes (Gottlieb, 1981).

ALD, CAT, GDH, GOT, GP, GPI, LAP, MDH, NADHD and PGM were stained as in Brown et al. (1978). ACO was stained as in Chenicek \& Hart (1987), EP was stained as in Tang \& Hart (1975), EST was stained as in Jaaska (1980), GAPD was

Table 1 Locations where Aegilops squarrosa plant material was collected. Ssp. eusquarrosa and ssp. strangulata populations are designated as 'e' and 's', respectively

\begin{tabular}{|c|c|c|c|c|c|}
\hline $\begin{array}{l}\text { Location } \\
\text { number }\end{array}$ & Population & Locality & Longitude $^{1}$ & Latitude $^{1}$ & Altitude (m) \\
\hline & & Dagestan & & & \\
\hline 1 & $1 \mathrm{e}$ & Vicinity of Gedzhuh village & 48.07 & 42.09 & 120 \\
\hline 2 & $2 \mathrm{~s}$ & Vicinity of Ersy village & 48.04 & 42.07 & 200 \\
\hline 3 & $3 \mathrm{~s}$ & Vicinity of Darvag village & 48.05 & 42.03 & 300 \\
\hline 4 & $4 \mathrm{e}, 4 \mathrm{~s}$ & Vicinity of Hily village & 48.07 & 41.95 & 450 \\
\hline 5 & $5 \mathrm{e}$ & Vicinity of Maraga village & 48.11 & 41.94 & 420 \\
\hline 6 & $6 e, 6 s$ & Vicinity of Rukel village & 48.24 & 41.98 & 380 \\
\hline 7 & $7 \mathrm{e}$ & The western foot of hill ' 336 ' & 48.26 & 41.98 & 160 \\
\hline 8 & $8 \mathrm{~s}$ & The top of hill ' 336 ' & 48.28 & 42.01 & 350 \\
\hline 9 & $9 \mathrm{e}, 9^{1} \mathrm{~s}, 9^{2} \mathrm{~s}$ & The eastern slope of hill ' 336 ' & 48.29 & 42.00 & 250 \\
\hline 10 & $10 \mathrm{e}$ & Vicinity of Novo-Maka village & 48.32 & 41.75 & 220 \\
\hline 11 & $11 \mathrm{e}$ & Vicinity of Novo-Usur village & 48.34 & 41.69 & 320 \\
\hline \multirow[t]{2}{*}{12} & $12 \mathrm{e}$ & Vicinity of Novo-Ganzah village & 48.35 & 41.63 & 370 \\
\hline & & Azerbaijan & & & \\
\hline 13 & $13 \mathrm{~s}$ & To the south from Hilmilly village & 48.88 & 40.64 & 1000 \\
\hline 14 & $14 \mathrm{~s}$ & To the south from Kalva village & 48.50 & 40.71 & 760 \\
\hline 15 & $15 \mathrm{~s}$ & Vicinity of Tirdjan village & 48.34 & 40.76 & 760 \\
\hline 16 & $16 \mathrm{~s}$ & Dzhebrail district, vicinity of Garar village & 47.01 & 39.42 & 700 \\
\hline \multirow[t]{2}{*}{17} & $17 \mathrm{~s}$ & Vicinity of Zangelan & 46.66 & 39.12 & 490 \\
\hline & & Armenia & & & \\
\hline 18 & $18 \mathrm{e}$ & Azizlekov - Sisian zoad, near the turn to Dzhezmuk & 45.56 & 39.69 & 1400 \\
\hline 19 & $19 \mathrm{e}$ & Vicinity of Noravank village & 45.32 & 39.77 & 1400 \\
\hline & & Nakhitshevan & & & \\
\hline 20 & $20 \mathrm{e}$ & To the north-west from Nakhitshevan city & 45.24 & 39.28 & 980 \\
\hline
\end{tabular}

${ }^{1}$ Given in decimals. 
stained as in Harris \& Hopkinson (1976) and SKDH was stained as in Neuman \& Hart (1983).

ACPH was visualized with $40 \mathrm{~mL} 0.1$ Tris- $\mathrm{HCl}$ buffer, $\mathrm{pH} 5.8$, containing $40 \mathrm{mg}$ of 1-naphthyl phosphate and $40 \mathrm{mg}$ of Fast Garnet GBC salt. Prior to staining, the gel was soaked for $1 \mathrm{~h}$ at $4^{\circ} \mathrm{C}$ in $0.2 \mathrm{M}$ Tris- $\mathrm{HCl}$ buffer, $\mathrm{pH}$ 5.8. Though soaking decreases the total number of ACPH bands scorable, it provides a high intensity of ACPH1, which is of major interest.

Because the character used by Eig (1929) for the separation of Ae. squarrosa into the subspecies is de facto a quantitative trait, a subspecies index (SI) reflecting the $A$ e. squarrosa spike constitution was worked out. SI was calculated as the ratio of the width of a spikelet glume to the width of the upper part of a rachis segment of the same spikelet. The spikelet from the very middle of the spike was taken for the measurement.

The SIGAMD statistical package was used for conducting principal component analysis, and the

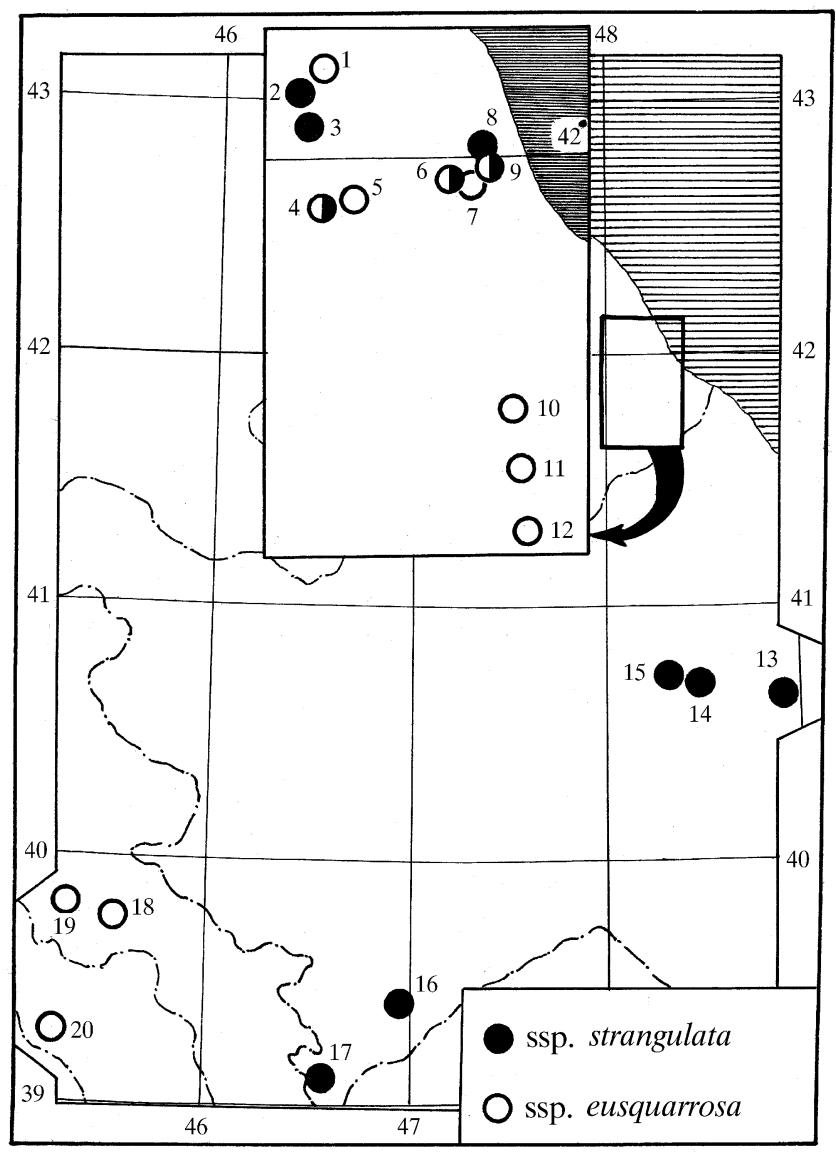

Fig. 1 Geographical distribution of sampling localities of Aegilops squarrosa. author's program written in Pascal was used for conducting multiple correspondence analysis (Lebart et al., 1984).

\section{Results and discussion}

Multiple loci in an enzyme system are numbered starting with the most anodal zone. Superscripts on the alleles indicate the relative migration distance on the gel, taking the most frequently found allele as 100 (Table 2). No heterozygotes were found in this study.

EP (endopeptidase) showed on zymograms as two major bands usually supplemented with a third faint band. A preliminary genetic study revealed that different EP zymogram patterns were inherited as allelic variants of a single $E p$ locus. Superscripts on $E p$ alleles are given as double numbers, the first number corresponding to the faster EP band.

\section{Variation among locations and populations}

In locations 4, 6 and 9 Ae. squarrosa was approximately equally represented by the two subspecies. Allozyme data reveal that Ae. squarrosa ssp. strangulata in location 9 is represented by a mixture of two populations, evidently owing to some recent migration event. The population $9^{1} \mathrm{~s}$, as will be shown below, has been isolated since ancient times. The migration event has taken place in very recent years, because no genetic exchange between $9^{1} \mathrm{~s}$ and $9^{2} \mathrm{~s}$ was indicated (Table 2). It was probably the construction of a serpentine road which caused the increase in migration between Ae. squarrosa populations located on the slope of hill '336'.

According to Zhukovsky (1928) and Eig (1929), the primary species of the genus Aegilops spread out at the end of the Tertiary period. The ancient geographical expansion of Ae. squarrosa is reflected in the allozyme spatial distribution patterns. The locations where rare alleles are found are scattered sporadically throughout the species' range (Dudnikov \& Goncharov, 1993). High frequency of an unusual allele in a population is a rare event, although independent events of this kind were found, suggesting that Ae. squarrosa has been occupying its range for a long time. For example, the Aco $2^{90}$ allele was first found in two neighbouring populations of ssp. strangulata in northern Iran and also about $1700 \mathrm{~km}$ to the east in a population of ssp. eusquarrosa from Uzbekistan (Dudnikov \& Goncharov, 1993). Examples of the separate origin of rare alleles also occur in this study. These are: $E^{99-100}$ (populations $\left.7 \mathrm{e}-13 \mathrm{~s}, 14 \mathrm{~s}\right)$, Est $^{66}(6 \mathrm{e}-12 \mathrm{e})$ 
and $M d h 2^{90}\left(8 \mathrm{~s}, 9^{1} \mathrm{~s}-16 \mathrm{~s}\right)$. The Got $3^{125}$ allele, which was previously found only in populations from south-eastern Azerbaijan (Jaaska, 1981; Dudnikov \& Goncharov, 1993), was found in population 2s, one of the most northern Dagestan populations. The same rare alleles were also found in neighbouring populations $\left(E p^{99-100}\right.$ in populations $13 \mathrm{~s}, 14 \mathrm{~s} ; E p^{100-102}$ in $3 \mathrm{~s}, 4 \mathrm{~s} ; M d h 2^{90}$ in $8 \mathrm{~s}, 9^{1} \mathrm{~s}$; Est $1^{97}$ in $19 \mathrm{e}, 20 \mathrm{e}$ ) indicating some migration between the populations or the origin of neighbouring populations from the same ancestral population (Fig. 1, Table 2).

This study reveals that sspp. eusquarrosa and strangulata differ distinctly in their ecology, morphology and allozyme variation. Ssp. strangulata is found in more moist, higher-located habitats (Fig. 2). Heading in ssp. strangulata begins about two weeks later than in ssp. eusquarrosa. There is also a clear-cut distinction in SI values between the populations of the two subspecies, with population $4 \mathrm{e}$ being the only exception (Fig. 3). Finally, differentiation is clearly demonstrated by the first principal component in a principal component analysis of allozyme variation (Fig. 4).

Data on genetic variation at the 27 enzyme loci studied (Table 2) were used to estimate the relative magnitude of genetic differentiation among populations of Ae. squarrosa. Nei's coefficient of gene differentiation $G_{\mathrm{ST}}$ was 0.67 for ssp. eusquarrosa and 0.64 for ssp. strangulata populations.

Although Ae. squarrosa is a self-pollinating species (Berlyand-Kozhevnikov \& Boguslavsky, 1979), examples of occasional cross-pollination have been found in VIR (Vavilov All-Russian Institute of Plant Industry, St.-Petersburg) accessions (Dudnikov, unpublished data). Evidently, in natural populations, where Ae. squarrosa grows sparsely, cross-pollination takes place more rarely than in VIR sown plots used for regenerating germ-plasm material.

Table 2 Allele frequencies at 11 polymorphic loci in populations of Aegilops squarrosa

\begin{tabular}{|c|c|c|c|c|c|c|c|c|c|c|c|c|}
\hline \multirow{3}{*}{$\begin{array}{l}\text { Population } \\
N \text { : }\end{array}$} & \multicolumn{12}{|c|}{ Ssp. eusquarrosa } \\
\hline & $1 \mathrm{e}$ & $4 \mathrm{e}$ & $5 e$ & $6 \mathrm{e}$ & $7 \mathrm{e}$ & $9 \mathrm{e}$ & $10 \mathrm{e}$ & $11 \mathrm{e}$ & $12 \mathrm{e}$ & $18 \mathrm{e}$ & $19 \mathrm{e}$ & $20 \mathrm{e}$ \\
\hline & 16 & 16 & 16 & 16 & 22 & 9 & 16 & 16 & 16 & 13 & 11 & 15 \\
\hline$A c p h 1^{100}$ & 1.00 & 1.00 & 1.00 & 1.00 & 1.00 & 1.00 & 1.00 & 1.00 & 1.00 & 1.00 & 1.00 & 1.00 \\
\hline Acph $1^{95}$ & 0 & 0 & 0 & 0 & 0 & 0 & 0 & 0 & 0 & 0 & 0 & 0 \\
\hline$E p^{100-102}$ & 0 & 0 & 0 & 0 & 0 & 0 & 0 & 0 & 0 & 0 & 0 & 0 \\
\hline$E p^{100-100}$ & 0.31 & 0 & 0 & 0.50 & 0.59 & 1.00 & 0.13 & 0.94 & 0.63 & 1.00 & 0.09 & 0 \\
\hline$E p^{99-100}$ & 0 & 0 & 0 & 0 & 0.32 & 0 & 0 & 0 & 0 & 0 & 0 & 0 \\
\hline$E p^{97-98}$ & 0 & 0 & 0 & 0 & 0 & 0 & 0 & 0 & 0 & 0 & 0 & 0 \\
\hline$E p^{97-96}$ & 0.06 & 0 & 1.00 & 0 & 0.09 & 0 & 0 & 0.06 & 0 & 0 & 0.09 & 1.00 \\
\hline$E p^{97-94}$ & 0.63 & 1.00 & 0 & 0.50 & 0 & 0 & 0.87 & 0 & 0.37 & 0 & 0.82 & 0 \\
\hline Est ${ }^{103}$ & 0 & 0 & 0 & 0 & 0 & 0 & 0 & 0 & 0 & 0 & 0 & 0 \\
\hline Est ${ }^{100}$ & 1.00 & 1.00 & 1.00 & 1.00 & 1.00 & 1.00 & 1.00 & 1.00 & 1.00 & 1.00 & 0.91 & 0.93 \\
\hline Est $1^{97}$ & 0 & 0 & 0 & 0 & 0 & 0 & 0 & 0 & 0 & 0 & 0.09 & 0.07 \\
\hline Est $2^{100}$ & 1.00 & 1.00 & 1.00 & 1.00 & 0.86 & 1.00 & 1.00 & 1.00 & 1.00 & 0.15 & 1.00 & 1.00 \\
\hline Est $2^{\text {null }}$ & 0 & 0 & 0 & 0 & 0.14 & 0 & 0 & 0 & 0 & 0.85 & 0 & 0 \\
\hline$E s t 2^{84}$ & 0 & 0 & 0 & 0 & 0 & 0 & 0 & 0 & 0 & 0 & 0 & 0 \\
\hline Est $5^{170}$ & 0.56 & 0 & 0 & 0 & 0 & 0 & 0.13 & 0 & 0 & 0 & 0.91 & 0.80 \\
\hline Est $5^{100}$ & 0.44 & 1.00 & 1.00 & 0.87 & 1.00 & 1.00 & 0.87 & 1.00 & 0.94 & 1.00 & 0.09 & 0.20 \\
\hline$E s t 5^{66}$ & 0 & 0 & 0 & 0.13 & 0 & 0 & 0 & 0 & 0.06 & 0 & 0 & 0 \\
\hline Got $1^{100}$ & 1.00 & 1.00 & 1.00 & 1.00 & 1.00 & 1.00 & 1.00 & 1.00 & 1.00 & 1.00 & 1.00 & 1.00 \\
\hline Got $1^{95}$ & 0 & 0 & 0 & 0 & 0 & 0 & 0 & 0 & 0 & 0 & 0 & 0 \\
\hline Got $2^{105}$ & 0.13 & 0 & 1.00 & 0 & 0 & 0 & 0 & 0 & 0 & 0 & 0 & 0 \\
\hline Got $2^{100}$ & 0.87 & 1.00 & 0 & 1.00 & 1.00 & 1.00 & 1.00 & 1.00 & 1.00 & 1.00 & 1.00 & 1.00 \\
\hline Got $3^{125}$ & 0 & 0 & 0 & 0 & 0 & 0 & 0 & 0 & 0 & 0 & 0 & 0 \\
\hline Got $3^{100}$ & 1.00 & 1.00 & 1.00 & 1.00 & 1.00 & 1.00 & 1.00 & 1.00 & 1.00 & 1.00 & 1.00 & 1.00 \\
\hline $\operatorname{Lap}^{107}$ & 0.06 & 0 & 0 & 0 & 0 & 0 & 0 & 0 & 0 & 0 & 0 & 0 \\
\hline Lap ${ }^{100}$ & 0.94 & 1.00 & 1.00 & 1.00 & 1.00 & 1.00 & 1.00 & 1.00 & 1.00 & 1.00 & 1.00 & 1.00 \\
\hline $\operatorname{Mdh} 2^{100}$ & 1.00 & 1.00 & 1.00 & 1.00 & 1.00 & 1.00 & 1.00 & 1.00 & 1.00 & 1.00 & 1.00 & 1.00 \\
\hline$M d h 2^{90}$ & 0 & 0 & 0 & 0 & 0 & 0 & 0 & 0 & 0 & 0 & 0 & 0 \\
\hline Nadhd $2^{100}$ & 1.00 & 1.00 & 1.00 & 1.00 & 0.91 & 1.00 & 1.00 & 1.00 & 1.00 & 1.00 & 1.00 & 1.00 \\
\hline $\operatorname{Nadhd} 2^{92}$ & 0 & 0 & 0 & 0 & 0.09 & 0 & 0 & 0 & 0 & 0 & 0 & 0 \\
\hline
\end{tabular}


Table 2 Continued

\begin{tabular}{|c|c|c|c|c|c|c|c|c|c|c|c|c|}
\hline \multirow{3}{*}{$\begin{array}{l}\text { Population } \\
N \text { : }\end{array}$} & \multicolumn{12}{|c|}{ Ssp. strangulata } \\
\hline & $2 \mathrm{~s}$ & $3 \mathrm{~s}$ & $4 \mathrm{~s}$ & $6 s$ & $8 \mathrm{~s}$ & $9^{1} \mathrm{~s}$ & $9^{2} \mathrm{~s}$ & $13 \mathrm{~s}$ & $14 \mathrm{~s}$ & $15 \mathrm{~s}$ & $16 \mathrm{~s}$ & $17 \mathrm{~s}$ \\
\hline & 21 & 16 & 18 & 16 & 16 & 9 & 3 & 16 & 16 & 16 & 16 & 12 \\
\hline Acph1 $1^{100}$ & 0 & 0 & 0 & 0 & 0 & 0 & 0 & 0 & 0 & 0 & 0 & 0 \\
\hline Acph $1^{95}$ & 1.00 & 1.00 & 1.00 & 1.00 & 1.00 & 1.00 & 1.00 & 1.00 & 1.00 & 1.00 & 1.00 & 1.00 \\
\hline$E p^{100-102}$ & 0 & 0.06 & 0.17 & 0 & 0 & 0 & 0 & 0 & 0 & 0 & 0 & 0 \\
\hline$E p^{100-100}$ & 1.00 & 0.94 & 0.66 & 1.00 & 1.00 & 0 & 1.00 & 0 & 0.50 & 0.25 & 0.19 & 0.25 \\
\hline$E p^{99-100}$ & 0 & 0 & 0 & 0 & 0 & 0 & 0 & 0.87 & 0.44 & 0 & 0 & 0 \\
\hline$E p^{97-98}$ & 0 & 0 & 0 & 0 & 0 & 0 & 0 & 0 & 0 & 0 & 0 & 0.42 \\
\hline$E p^{97-96}$ & 0 & 0 & 0 & 0 & 0 & 1.00 & 0 & 0 & 0 & 0 & 0.81 & 0.33 \\
\hline$E p^{97-94}$ & 0 & 0 & 0.17 & 0 & 0 & 0 & 0 & 0.13 & 0.06 & 0.75 & 0 & 0 \\
\hline Est ${ }^{103}$ & 0 & 0 & 0 & 0 & 0 & 1.00 & 0 & 0 & 0 & 0 & 0 & 0 \\
\hline Est ${ }^{100}$ & 1.00 & 1.00 & 1.00 & 1.00 & 1.00 & 0 & 1.00 & 1.00 & 1.00 & 1.00 & 1.00 & 1.00 \\
\hline Est ${ }^{97}$ & 0 & 0 & 0 & 0 & 0 & 0 & 0 & 0 & 0 & 0 & 0 & 0 \\
\hline Est2 ${ }^{100}$ & 0.48 & 0.50 & 0.28 & 0.19 & 1.00 & 0 & 1.00 & 0 & 0.19 & 0.13 & 0.19 & 0.25 \\
\hline Est2 $2^{\text {null }}$ & 0 & 0 & 0 & 0 & 0 & 1.00 & 0 & 1.00 & 0.62 & 0.68 & 0.62 & 0 \\
\hline Est ${ }^{84}$ & 0.52 & 0.50 & 0.72 & 0.81 & 0 & 0 & 0 & 0 & 0.19 & 0.19 & 0.19 & 0.75 \\
\hline Est $5^{170}$ & 1.00 & 1.00 & 0.83 & 1.00 & 1.00 & 1.00 & 1.00 & 1.00 & 0.87 & 1.00 & 1.00 & 1.00 \\
\hline Est $5^{100}$ & 0 & 0 & 0.17 & 0 & 0 & 0 & 0 & 0 & 0.13 & 0 & 0 & 0 \\
\hline Est $5^{66}$ & 0 & 0 & 0 & 0 & 0 & 0 & 0 & 0 & 0 & 0 & 0 & 0 \\
\hline Got1 100 & 0.71 & 0.87 & 0.94 & 0.94 & 1.00 & 1.00 & 1.00 & 1.00 & 0.37 & 0.63 & 0.56 & 1.00 \\
\hline Got $1^{95}$ & 0.29 & 0.13 & 0.06 & 0.06 & 0 & 0 & 0 & 0 & 0.63 & 0.37 & 0.44 & 0 \\
\hline Got $2^{105}$ & 1.00 & 1.00 & 0.89 & 1.00 & 1.00 & 1.00 & 1.00 & 1.00 & 1.00 & 1.00 & 1.00 & 1.00 \\
\hline Got $2^{100}$ & 0 & 0 & 0.11 & 0 & 0 & 0 & 0 & 0 & 0 & 0 & 0 & 0 \\
\hline Got $3^{125}$ & 0.14 & 0 & 0 & 0 & 0 & 0 & 0 & 0 & 0 & 0 & 0 & 0 \\
\hline Got $3^{100}$ & 0.86 & 1.00 & 1.00 & 1.00 & 1.00 & 1.00 & 1.00 & 1.00 & 1.00 & 1.00 & 1.00 & 1.00 \\
\hline $\operatorname{Lap}^{107}$ & 0 & 0 & 0 & 0 & 0 & 0 & 0 & 0 & 0 & 0 & 0 & 0 \\
\hline Lap ${ }^{100}$ & 1.00 & 1.00 & 1.00 & 1.00 & 1.00 & 1.00 & 1.00 & 1.00 & 1.00 & 1.00 & 1.00 & 1.00 \\
\hline$M d h 2^{100}$ & 1.00 & 1.00 & 1.00 & 1.00 & 0 & 0 & 1.00 & 1.00 & 1.00 & 1.00 & 0.94 & 1.00 \\
\hline$M d h 2^{90}$ & 0 & 0 & 0 & 0 & 1.00 & 1.00 & 0 & 0 & 0 & 0 & 0.06 & 0 \\
\hline Nadhd $2^{100}$ & 1.00 & 1.00 & 1.00 & 1.00 & 1.00 & 0 & 1.00 & 1.00 & 1.00 & 1.00 & 1.00 & 1.00 \\
\hline Nadhd $2^{92}$ & 0 & 0 & 0 & 0 & 0 & 1.00 & 0 & 0 & 0 & 0 & 0 & 0 \\
\hline
\end{tabular}

$N$, number of individuals sampled per population.

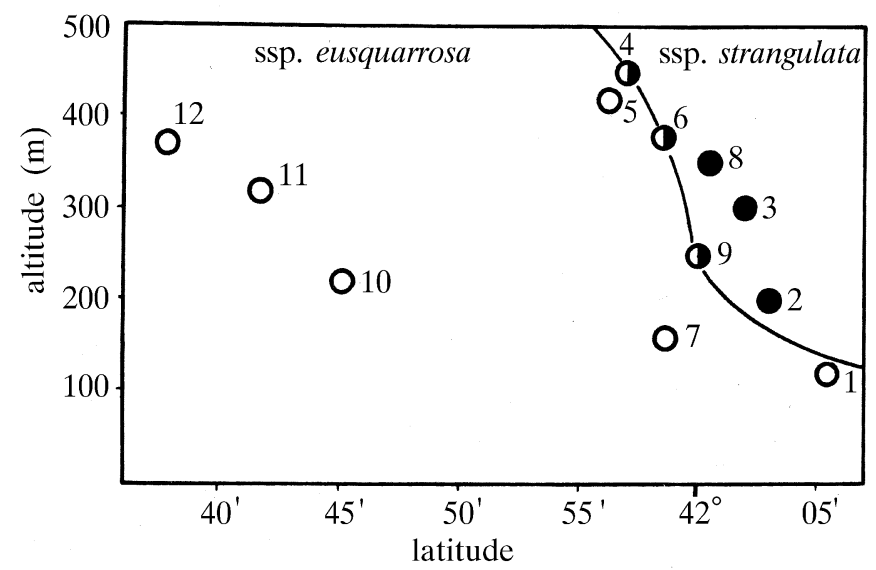

Fig. 2 The 12 Dagestan primary habitats of Aegilops squarrosa.
As expected from the Ae. squarrosa mating system and apparently low $N_{\mathrm{e}}$ values, linkage disequilibrium is usually found, although in some populations (1e, $16 \mathrm{~s}, 15 \mathrm{~s})$ deviation from gametic phase equilibrium is not significant (Fig. 5).

Despite sharing the same habitat, populations 6s and 6e display no signs of introgression (Table 2, Fig. 3). In contrast, for populations $4 \mathrm{~s}$ and $4 \mathrm{e}$ introgression between the two subspecies is quite obvious. Population $4 \mathrm{e}$ stands out from all the other ssp. eusquarrosa populations in having a distinct displacement of the SI values towards the moniliform type of spike (Fig. 3). Allozyme variation in $A e$. squarrosa populations from location 4 also reveals genetic exchange between the two subspecies (Fig. 6).

Although genetic exchange between sspp. strangulata and eusquarrosa was not found in location 9

(C) The Genetical Society of Great Britain, Heredity, 80, 248-258. 


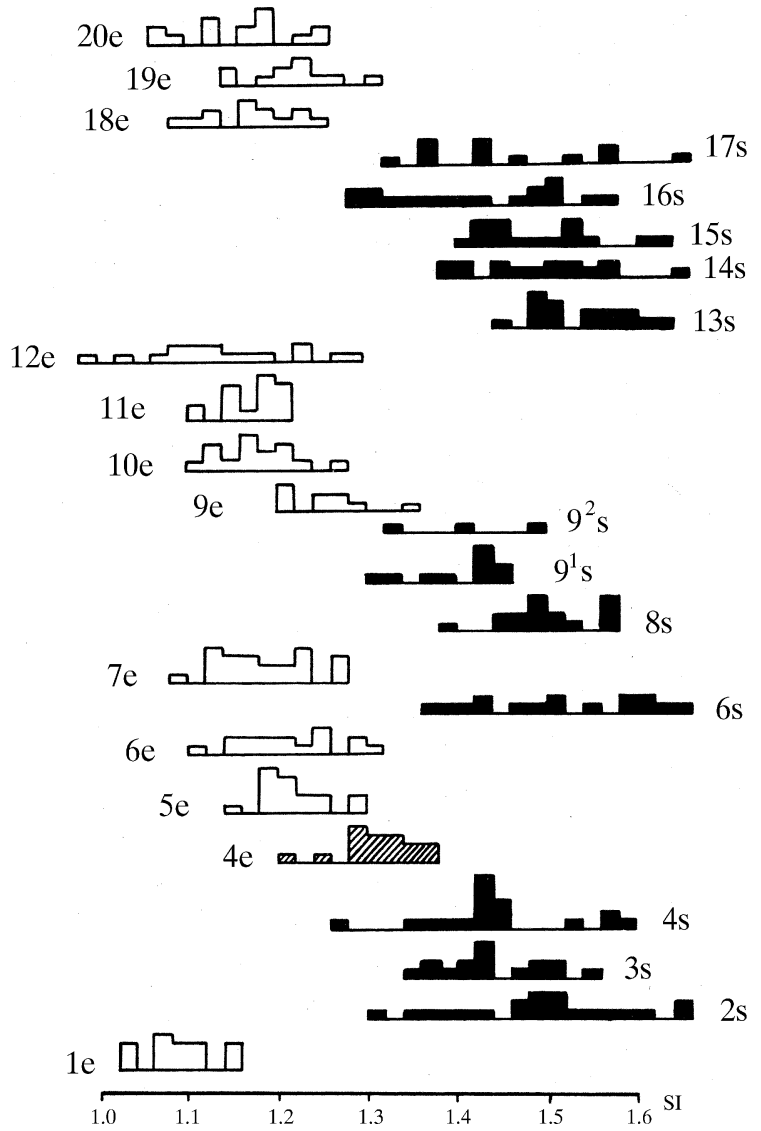

Fig. 3 Distributions of subspecies index (SI) values in Aegilops squarrosa populations.

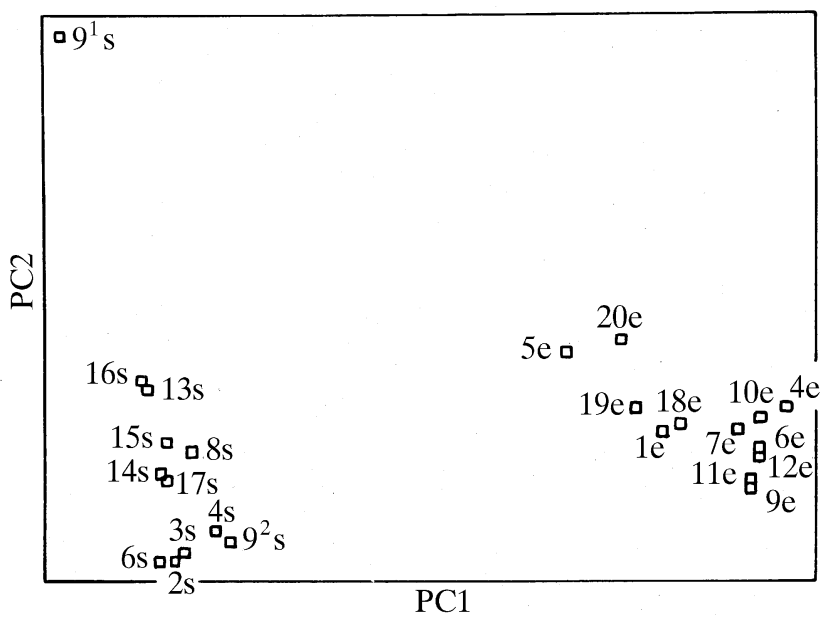

Fig. 4 Graph of the first two axes from a principal components analysis based on allele frequencies of Aegilops squarrosa populations analysed. directly, the spatial distributions of the alleles $N a d h d 2^{92}$ and $E p^{97-96}$ provide some evidence that introgression has taken place somewhere in the vicinity of hill ' 336 '. Both $N a d h d 2^{92}$ and $E p^{97-96}$ attain a frequency of 100 per cent in the $9^{1}$ s population of ssp. strangulata. The neighbouring $7 \mathrm{e}$ population of ssp. eusquarrosa is the only other population in this and the previous study (Dudnikov \& Goncharov, 1993) where the Nadhd $2^{92}$ allele was found. It was also the only other population among those in the vicinity of hill ' 336 ' $\left(6 \mathrm{~s}, 6 \mathrm{e}, 7 \mathrm{e}, 8 \mathrm{~s}, 9^{1} \mathrm{~s}, 9^{2} \mathrm{~s}, 9 \mathrm{e}\right)$ where the $E p^{97-96}$ allele was found (Table 2). In population 7e the plants which had the Nadhd $2^{92}$ allele were the only ones which had the $E p^{97-96}$ allele (Fig. 5).

Ep, Est 2 and Got 1 are commonly polymorphic in ssp. strangulata, so that the spatial distribution of $E p$ allele frequencies can be compared with those of Est 2 and Got1. When Ep is considered, $9^{1}$ s stands apart from all the other ssp. strangulata populations because it is the only one in which the allele $E p^{97-96}$ had a frequency of 100 per cent. For the other 11 populations, it can be seen that the allozyme variation patterns correspond in general with the geographical distances between the populations (Fig. 7). The spatial distribution patterns of the Est 2 and Got 1 allele frequencies are quite different from those of Ep, displaying no correlation with the geographical distance between populations. Geographically distant populations can be remarkably similar, whereas neighbouring populations can differ greatly (Fig. 8). In general, the eastern Dagestan populations $8 \mathrm{~s}, 9^{1} \mathrm{~s}$ and $9^{2} \mathrm{~s}$ and the most eastern among the Azerbaijan group of populations (13s) all lack both the Est2 ${ }^{84}$ and Got $1^{95}$ alleles. When the other eight populations of ssp. strangulata are considered, the Est ${ }^{84}$ frequency correlates negatively with the frequency of $\operatorname{Got}^{95} \quad(r=-0.91$, $P<0.002)$.

\section{Differences among loci}

The 27 enzyme loci studied fall into four reasonably distinct groups.

1 The monomorphic loci: Aco1, Aco2, Acph4, Ald, Cat1, Cat2, Est3, Est4, Gapd, Gdh, Gp, Gpi, Mdh1, Nadhd1, Pgm, Skdh.

2 Est1, Got3, Lap, Mdh2, Nadhd2. In most populations each of these loci is represented only by its common allele. If a rare allele was found, it either had a low frequency or was fixed.

$3 E p$. This is the highly polymorphic locus with variation patterns similar in both the subspecies.

4 Acph1, Est2, Est5, Got1, Got2. Their allozyme variation patterns differ greatly between the two 
subspecies. These were the five loci in which allozyme variation separated Ae. squarrosa into ssp. eusquarrosa and ssp. strangulata along the first principal component in Fig. 4.

Lewontin (1985) criticized the rather common approach in population genetics studies of treating different loci as a homogeneous collection. It was emphasized that the correct classification of different loci in terms of the general forces acting on them is desirable. In the case of Ae. squarrosa, heterogeneity among the enzyme loci studied is apparent.

The most probable reason for the monomorphism of the enzyme loci in the first group is purifying

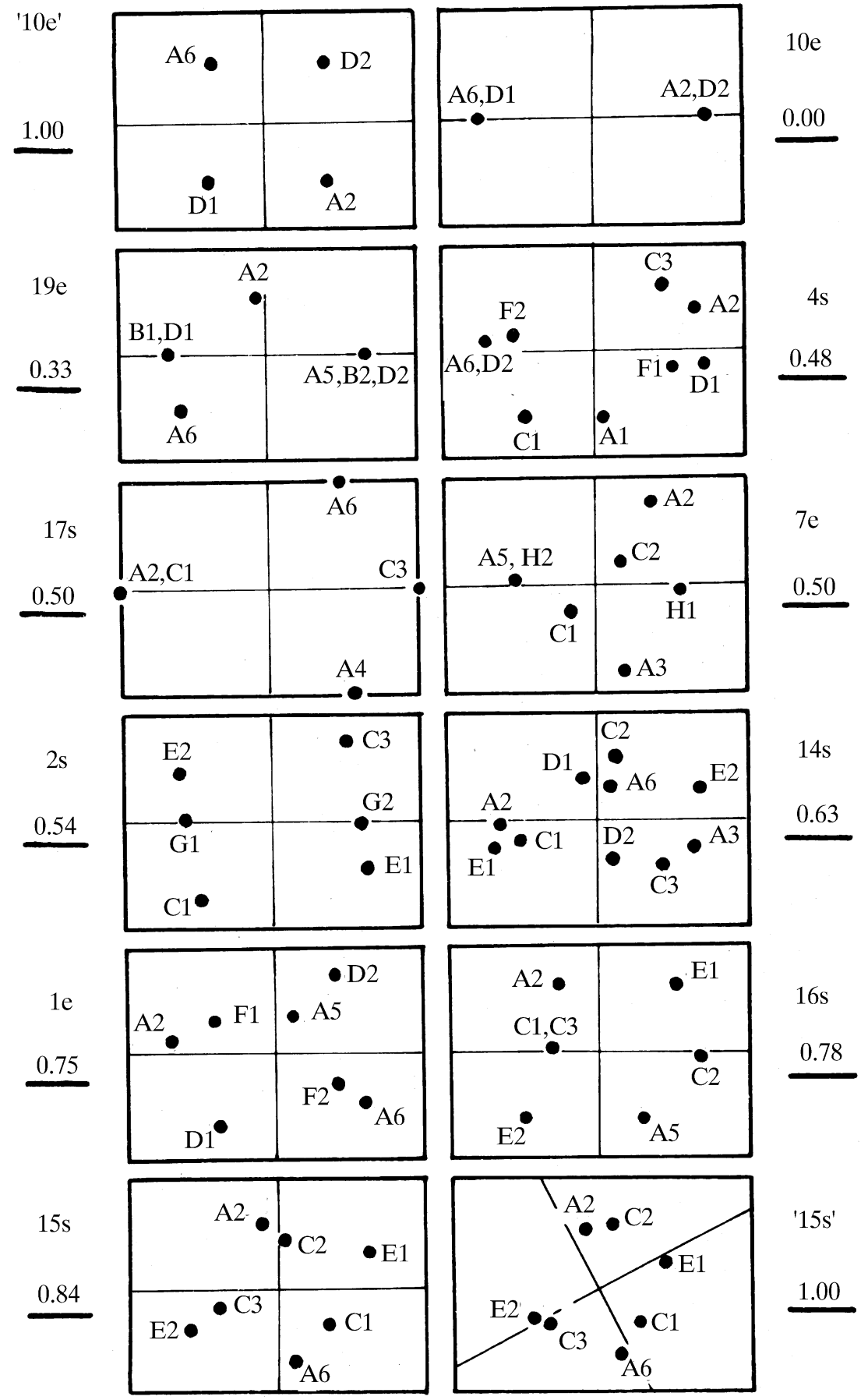

Fig. 5 Graphs of the first two axes from multiple correspondence analysis. For each population of Aegilops squarrosa, specimens were taken as variables and genetic markers as objects. A1, $E p^{100-102}$; A2, $E p^{100-100}$; $\mathrm{A} 3, E p^{99-100} ; \mathrm{A} 4, E p^{97-98} ; \mathrm{A} 5, E p^{97-96}$; A6, Ep ${ }^{97-94} ; \mathrm{B} 1$, Est $^{100}$; B2, Est $1^{97} ; \mathrm{C} 1$, Est ${ }^{100} ; \mathrm{C} 2$, Est $^{\text {null }}$; C3, Est $2^{84}$; D1, Est $5^{170}$; D2, Est $5^{100}$; E1, Got $1^{100}$; E2, Got1 $^{95}$; F1, Got2 ${ }^{105}$; F2, Got2 ${ }^{100}$; G1, Got $3^{125}$; G2, Got ${ }^{100} ; \mathrm{H} 1$, Nadhd $2^{100}$; $\mathrm{H} 2$, Nadhd $2^{92}$. The same location of alleles of different loci in the multidimensional space formed by the principal axes indicates 100 per cent association of the alleles in the population. The same projection of $\mathrm{C} 1$ and $\mathrm{C} 3$ in a plane formed by the first two principal axes (16s population) indicates that these Est 2 alleles display entirely the same association patterns with all the other genetic markers in the population. The ratio $\lambda_{2} / \lambda_{1}$ (the trivial eigenvalue $\lambda_{0}=1$ is not considered) is used as a general measure of the extent of linkage disequilibrium in a population. It can vary from 0 to 1 , the latter extreme value corresponding to the case of complete gametic phase equilibrium. $\lambda_{2} / \lambda_{1}$-values for each population are given as underlined numbers. The ' $10 \mathrm{e}$ ' and '15s' graphs give examples of how the patterns at the 10e and $15 \mathrm{~s}$ populations would look in the case of complete linkage equilibrium.

(C) The Genetical Society of Great Britain, Heredity, 80, 248-258. 


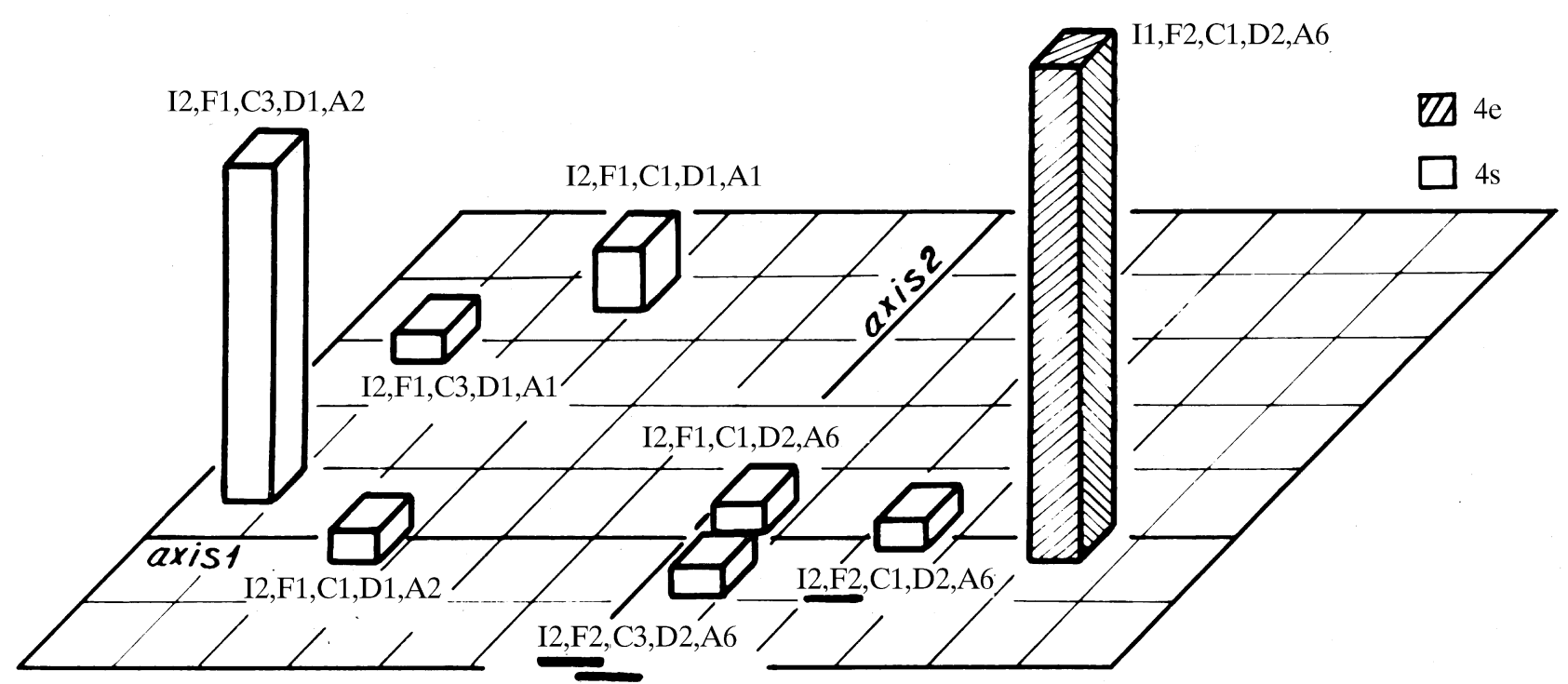

Fig. 6 The first two axes from multiple correspondence analysis. Genetic markers were taken as variables and the 34 specimens of both Aegilops squarrosa ssp. eusquarrosa and ssp. strangulata from location 4 were taken as objects. The number of specimens of each genotype found is reflected by the height of the column. Allele designations are listed in Fig. 5, except I1, Acph $1^{100}$; I2, Acph $1^{95}$. In the genotype descriptions only one allele of each locus is indicated because no heterozygotes were found. The unusual Ae. squarrosa gene combinations are underlined.

selection against alternative allelic variants. Low mutation rates of the loci are unlikely to be the cause, because the same locus in another environment, or its homologous locus in a closely related species, can be highly polymorphic. For example, Cat2, which is monomorphic in both Ae. squarrosa subspecies in the Transcaucasian region, is represented by three approximately equally common alleles in the eastern part of the Ae. squarrosa range inhabited by ssp. eusquarrosa (Dudnikov \& Goncharov, 1993). The Gdh, Gp and Gpi loci from the first group were found to be polymorphic in each of the five species of the Sitopsis group of Aegilops studied electrophoretically by Mendlinger \& Zohary (1995).

Rare alleles of the loci from the second group are likely to be slightly deleterious. These alleles never attain high frequencies, except for occasionally being fixed by genetic drift on account of the small size of the Ae. squarrosa populations (Table 2). If some of the Ae. squarrosa populations remained isolated and free from immigration over a long period of time, they may have become a 'trap' for rare alleles because of fixation of slightly deleterious alleles. It seems reasonable to suggest that population $9^{1} \mathrm{~s}$ or its ancestral population is an example of this (Table 2, Fig. 4). Another example is the accession VIR-1954, Iran, which has fixation of the alleles $A$ co $^{110}$ and Nadhd1 ${ }^{88}$ which have not been found anywhere else in Ae. squarrosa (Dudnikov \& Goncharov, 1993).

Obviously, the dividing line between the first and the second group of loci is to some extent arbitrary because it depends upon the amount of plant material studied. If the data on VIR Ae. squarrosa accessions studied earlier (Dudnikov \& Goncharov, 1993) are considered, the Aco2, Acph4, Mdh1, Nadhd1 and Pgm loci have to be assigned to the second group.

The loci from the remaining two groups are essentially polymorphic in Ae. squarrosa if the species is considered as a whole. Stochastic processes and/or natural selection may be the reasons for this polymorphism. In the case of Ae. squarrosa, neutral genes and genes under natural selection could be expected to display distinctly different variation patterns.

\section{Evolutionary considerations}

Aegilops squarrosa has inhabited its range since the end of the Tertiary period (Zhukovsky, 1928; Eig, 1929) so that the frequency distribution of any allele studied among local populations of any of the subspecies can be expected to be in equilibrium. Apparently, the population genetic structure of the two subspecies is not appreciably different, which is also reflected by the similar $G_{\mathrm{ST}}$ values in both 
subspecies. Thus, for a neutral gene, the distributions are expected to be similar in both the subspecies. Genetic exchange between the subspecies, which was found to be rather common, must also contribute to this similarity. By contrast, in the case of a gene under natural selection, the gene frequency distributions can differ widely in the two subspecies as a result of distinct differences in their ecology and genetic constitution.

It should be noted that, because Ae. squarrosa inhabits mountainous or hilly regions, geographically close habitats can be ecologically quite different, and conversely, habitats, which are geographically distant from one another, can be very similar in their

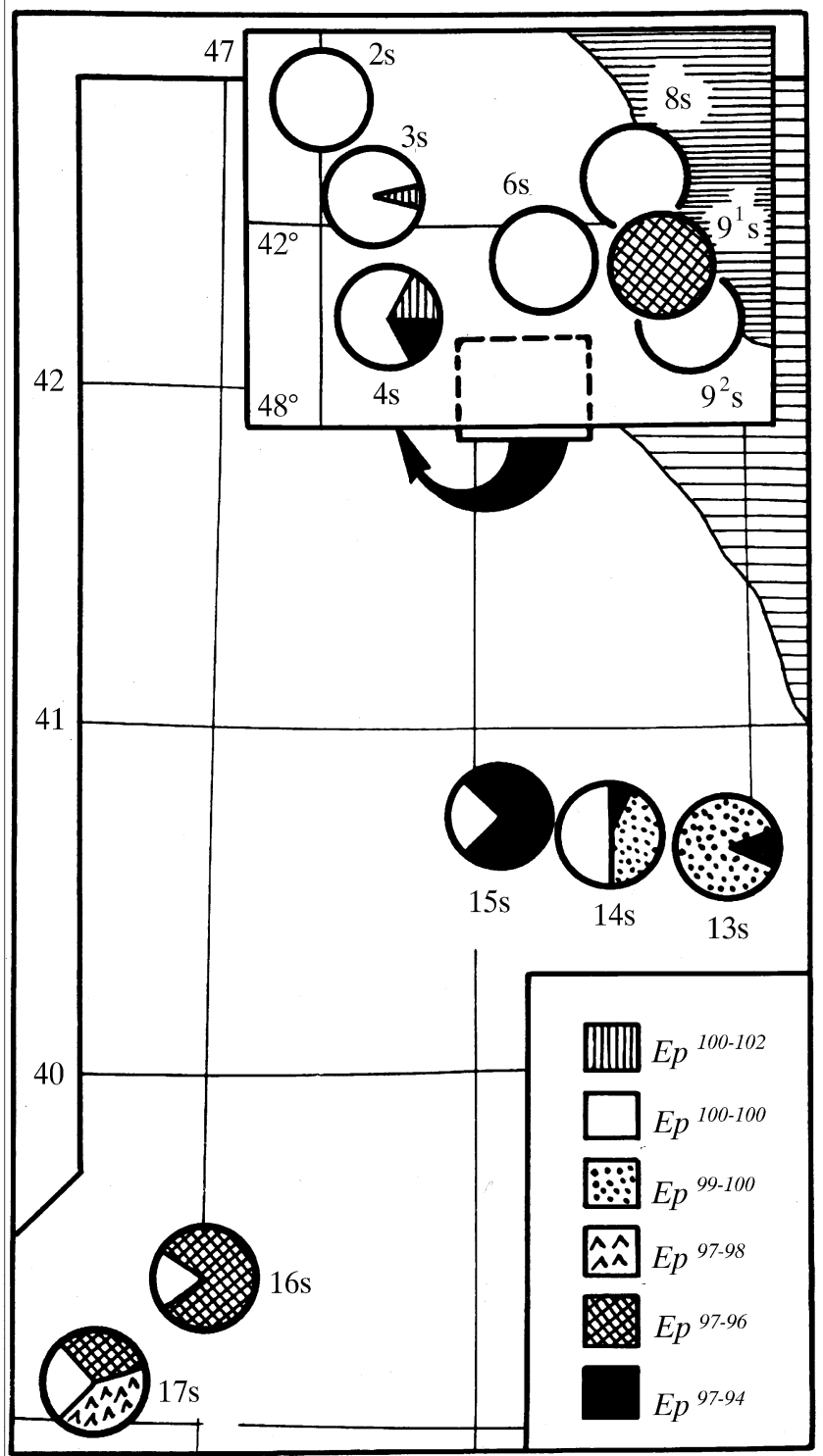

Fig. 7 Spatial distribution of Ep allele frequencies in Aegilops squarrosa ssp. strangulata populations. environmental conditions. So, allozyme variation, if under natural selection, can be expected to display, in general, no correlation with geographical distances between the populations. Allele frequencies at different loci may correlate with each other if they are under the influence of the same environmental factors. On the other hand, in the case of neutrality, similarity in allozyme variation patterns between geographically close populations may be expected as a result of migration or origins from the same ancestral population.

The fourth group of loci appear to be subjected to natural selection. Despite genetic exchange between

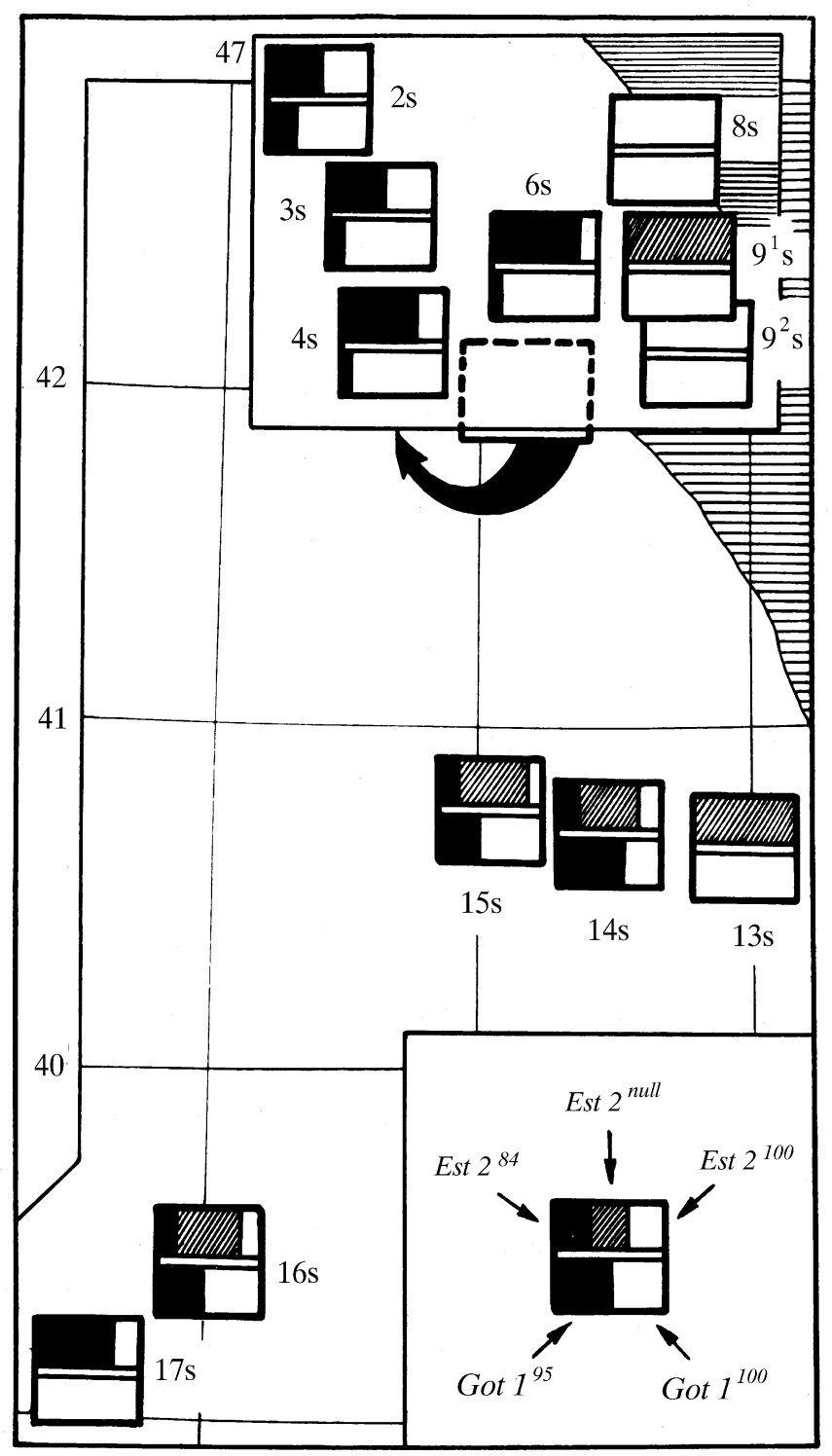

Fig. 8 Spatial distribution of Est2 and Got1 allele frequencies in Aegilops squarrosa ssp. strangulata populations.

(c) The Genetical Society of Great Britain, Heredity, 80, 248-258. 
the two subspecies, $A c p h 1^{95}$ is the only $A c p h 1$ allele that was found in ssp. strangulata, whereas ssp. eusquarrosa has exclusively the Acph $1^{100}$ allele. Got $2^{105}$, which is the only or predominant Got 2 allele in ssp. strangulata populations, displays in ssp. eusquarrosa the type of frequency distribution that is characteristic of the slightly deleterious alleles for loci in the second group. In ssp. strangulata, Got $1^{95}$ and $E s t 2^{84}$ display a distinctly asymmetrical, approximately hyperbolical type of frequency distribution, which could indicate natural selection (Wright, 1931, 1937). In ssp. eusquarrosa these alleles are completely absent, suggesting strong purifying selection (Table 2). The Got ${ }^{95}$ frequency correlates negatively with the frequency of Est ${ }^{84}$ in those populations of ssp. strangulata which have at least one of these alleles. The spatial distributions of the Got 1 and Est 2 allele frequencies (Fig. 8) are consistent with what is expected in the case of natural selection.

The neutrality model is the most likely explanation for the $E p$ variation patterns in Ae. squarrosa. Environmental factors seem to have no influence on $E p$ variation. All the five enzyme loci (Acph1, Cat2, Est2, Est5 and Got2) which in the previous study (Dudnikov \& Goncharov, 1993) were found to be essentially polymorphic in Ae. squarrosa in general, were polymorphic in some parts of the vast $A e$. squarrosa range but monomorphic in others. $E p$ remains polymorphic through all the Ae. squarrosa distribution from Georgia to Kirgizia (Dudnikov, unpublished data). Ep variation patterns are similar in ssp. eusquarrosa and ssp. strangulata (Table 2), despite the differences in the genetic constitutions and ecological preferences of the subspecies. $E p^{100-100}$, the most common $E p$ allele, displays an approximately regularly spaced frequency distribution in unfixed factors, which suggests neutrality (Wright, 1931, 1937). Ep displays spatial variation patterns that differ greatly from those of the loci under selection (Figs 7 and 8). As expected, there is similarity between the geographically close populations in their $E p$ variation patterns. Population $9^{1} \mathrm{~s}$ is the only marked exception, which is consistent with the evidence obtained from the variation patterns of the slightly deleterious alleles, that this population has been isolated for a long period of time.

According to Jaaska (1981), subspecies strangulata and eusquarrosa differentiated at the very beginning of the appearance of Ae. squarrosa as a species. It was an adaptive process, and five out of the 27 enzyme loci studied appear to have been involved in it. Despite the genetic exchange between them, ssp. eusquarrosa and ssp. strangulata remain as two distinct subspecies, suggesting that intermediate genotypes are disadvantageous.

Future intraspecies differentiation of Ae. squarrosa could finally lead to the origin of a new species through nonadaptive differentiation of small isolated populations. The populations $9^{1} \mathrm{~s}$ (Fig. 4) and VIR-1954, Iran, may be examples of such differentiation.

\section{Acknow ledgements}

I would like to express my sincere gratitude to Dr N. A. Navruzbekov and Dr A. A. Filatenko (Vavilov All-Russian Institute of Plant Industry, St.Petersburg), without whose kind help the collection of the plant material would not have been possible. I am very grateful to Dr O. E. Kosterin, Dr E. V. Levites and Dr A. A. Konovalov for their help in the course of this study. And I wish to thank Abdurashid M. Abdullaev who was an expedition car driver in both the Transcaucasian expeditions.

\section{References}

BERLYAND-KOZHEVNIKOV, V. M. AND BOGUSLAVSKY, R. L. 1979. The types of flowering and pollination of Aegilops L. species in southern Dagestan. Bull. Vavilov All-Russian Inst. Plant Industry, St.-Petersburg, 79, 58-62 (in Russian).

BRown, A. H. D., NEVO, E., ZOHARY, D. AND DAGAN, O. 1978. Genetic variation in natural populations of wild barley (Hordeum spontaneum). Genetica, 49, 97-108.

CHENICEK, K. J. AND HART, G. E. 1987. Identification and chromosomal locations of aconitase gene loci in Triticeae species. Theor. Appl. Genet., 74, 261-268.

DUdNikov, A. JU. AND GONCHARov, N. P. 1993. Allozyme variation in Aegilops squarrosa. Hereditas, 119, 117-122.

EIG, A. 1929. Monographisch-kritische öbersicht der Gattung Aegilops. Reportorium Specierum Novarum Regni Vegetabilis, Berhefte 55, pp. 1-228.

GOTTLIEB, L. D. 1981. Gene number in species of Astereae that have different chromosome numbers. Proc. Natl. Acad. Sci. U.S.A., 78, 3726-3729.

HARRIS, H. AND HOPKINSON, D. A. 1976. Handbook of Enzyme Electrophoresis in Human Genetics (with Supplements). North-Holland Publishing Co., Amsterdam.

HART, G. E. AND LANGSTON, P. J. 1977. Chromosomal location and evolution of isozyme structural genes in hexaploid wheat. Heredity, 39, 263-277.

JAASKA, v. 1980. Electrophoretic survey of seedling esterases in wheats in relation to their phylogeny. Theor. Appl. Genet., 56, 273-284.

JAASKA, v. 1981. Aspartate amino transferase and alcohol dehydrogenase enzymes: intraspecific differentiation in Aegilops tauschii and the origin of the D genome polyploids in the wheat group. Pl. Syst. Evol., 137, 259-273. 
JAASKA, v. 1984. NAD-dependent aromatic alcohol dehydrogenase in wheats (Triticum L.) and goat grasses (Aegilops L.): evolutionary genetics. Theor. Appl. Genet., 67, 535-540.

LAgudah, E. S. AND HAlloran, G. M. 1988. Phylogenetic relationships of Tritium tauschii the D genome donor to hexapod wheat. 1. Variation in HMW subunits of glutenin and gliadins. Theor. Appl. Genet., 75, 592-598.

LAUgudAh, E. S. AND HALlORAN, G. M. 1989. Phylogenetic relationships of Triticum tauschii the D genome donor to hexaploid wheat. 3. Variation in, and the genetics of, seed esterases (Est-5). Theor. Appl. Genet., 77, 851-856.

LEBART, L., MORINEAU, A. AND WARwick, K. M. 1984. Multivariate Descriptive Statistical Analysis. John Wiley, New York.

Lewontin, R. C. 1985. Population genetics. Ann. Rev. Genet., 19, 81-102.

LUBbers, E. L., GILL, K. S., COX, T. S. AND GILL, B. S. 1991. Variation of molecular markers among geographically diverse accessions of Triticum tauschii. Genome, 34, 354-361.
MENDLINGER, S. AND ZOHARY, D. 1995. The extent and structure of genetic variation in species of the Sitopsis group of Aegilops. Heredity, 74, 616-627.

NEUMAN, P. R. AND HART, G. E. 1983. Genetic control of shikimate dehydrogenase in hexaploid wheat. Biochem. Genet., 21, 963-968.

TANAKA, M. 1983. Geographical distribution of Aegilops species based on the collection at the plant germ-plasm institute, Kyoto University. In: Sakamoto, S. (ed.) Proc. 6th International Wheat Genetics Symposium, Kyoto, Japan, pp. 1009-1024.

TANG, K. S. AND HART, G. E. 1975. Use of isozymes as chromosome markers in wheat-rye addition lines and triticale. Genet. Res., 26, 187-201.

Wright, s. 1931. Evolution in Mendelian populations. Genetics, 16, 97-159.

Wright, s. 1937. The distribution of gene frequencies in populations. Proc. Natl. Acad. Sci. U.S.A., 23, 307-320.

ZHUKOvSKY, P. M. 1928. A critical-systematical survey of the species of the genus Aegilops L. Bull. Appl. Bot., Genet., Pl. Breed., 18, 417-609 (in Russian). 